\title{
The Effect of Three Techniques for Teaching English Idioms to Iranian TEFL Undergraduates
}

\author{
Zahra Fotovatnia \\ English Department, Faculty of Literature \& Humanities, Islamic Azad University, Najaf Abad Branch, Najafabad, Iran \\ Email: z.fotovatnia@iaun.ac.ir \\ Ghazal Khaki \\ English Department, Faculty of Literature \& Humanities, Islamic Azad University, Najaf Abad Branch, Najafabad, Iran \\ Email: gh_khaki@yahoo.com
}

\begin{abstract}
The present study investigated the effect of using picture, Persian translation equivalent (L1), and English definition (L2) on the learning of 20 decomposable and nondecomposable idioms by 68 Iranian TEFL undergraduates. The focus was on learning both meaning as well as form of the idioms. The idioms were given to the participants to translate into Persian three weeks before the experiment to ensure the participants' unfamiliarity of the idioms. The idioms that were known even by one student were crossed out. Each group of the participants received the instruction in 3 sessions (about 7 idioms each session), and reviewed them in the fourth. The participants received 2 recognition tests (one on form and the other on meaning of the L2 idioms) in the form of multiple-choice in the fifth session, and the same recognition as well as 2 production tests in the form of fill-in-the-blanks 3 weeks later (first on form and then on meaning). The delayed posttests were given in 2 consecutive sessions: first, the production and then the recognition. The findings showed that the picture group outperformed the other groups in all situations. However, a significant outperformance of L1 group over L2 group was observed for decomposable idioms in the first posttest regarding form. The results suggest the pedagogical value of pictures for the teaching of meaning and form of decomposable idioms.
\end{abstract}

Index Terms - type of instruction, $\mathrm{L} 1$ translation, $\mathrm{L} 2$ definition, idioms, recognition test, production test

\section{INTRODUCTION}

Idiomatic expressions are used in all forms of discourse: in conversations, lectures, movies, radio broadcasts, television programs, and so on as well as their usage is so common in English that it seems very difficult (and occasionally unnatural) for L2 learners to function effectively in an L2 communication context without the knowledge of idioms. Therefore, learning English idioms is essential to L2 learners, and every L2 learner must prepare himself or herself to meet these challenges. In fact, L2 learners should learn not only the grammatical structures and vocabulary of the target language but the idioms as well to integrate into the culture of the L2. A study by Seccord and Wiig (1993) confirmed that the knowledge of idioms is essential in reading and social communication.

But what are idioms? How do they differ from other forms of language? What are their different aspects? Idioms are fixed expressions that belong to the conventional repertoire of the native speakers of a language. Both meaning and form of these utterances are standardized, often allowing for only minimal variation. Fixed expressions are phrasal units, and they exist in many varieties (e.g., phrasal verbs, restricted collocations, idiomatic expressions, sayings, and proverbs). Idiomatic expressions or idioms are a particularly interesting variant of fixed expressions, because their meaning is partly or completely non compositional (Sprenger et al., 2006). That is, the relationship between the meanings of the words that make up the idiom and the idiom as a whole is at best indirect, if there is any relation at all. This is most obvious in idioms that are opaque, like, for example, kick the bucket. The literal meaning of this phrase does not suggest its figurative meaning to die. Still, native speakers of English know that the phrase last night Jim kicked the bucket means Jim is dead. Of course, a literal reading is not excluded; for example, in a context where there is a discussion about people kicking the buckets, the literal reading is preferred (they are kicking the bucket).

With this brief background in mind, the current study examines the effect of different techniques to teaching idioms on the learning of L2 Learners. More precisely, this study compares the performance of three groups of L2 learners on both recognition and production tasks including decomposable idioms after they have been exposed to these idioms through providing the first group with the L1 translation, the second group with L2 definition and synonyms, and the third group with their corresponding pictures.

\section{BACKGROUND TO THE STUDY}

Traditionally, idioms have been described as long words that syntactically and semantically behave as lexical entries. Consider the idiomatic expression kick the bucket: The literal meaning of the expression to strike a bucket with one's 
foot has no obvious semantic overlap with the figurative meaning of the expression to die suddenly. This noncompositional definition of idioms has been proposed by linguists like Chomsky (1980) and Fraser (1970), and psycholinguists like Bobrow and Bell (1973) and Titone (1999).

The clarification of idioms as noncompositional unitary word strings, which was evident in early psycholinguistic studies and models of idiom comprehension, was due to the fact that traditional models of "literal" language comprehension, in which phrasal meaning is based on a strict compositional analysis, could address how figurative meaning are realized during comprehension. All models of idioms processing that has been proposed at that time assumed that idiom comprehension simply requires memory retrieval of stipulated idiomatic meanings (Titone, 1999).

Based on this view, these expressions are noncompositional because their figurative meanings are not the functions of the meanings of their individual parts (Chomsky, 1965; Cooper, 1986). For instance, the figurative interpretation of shoot the breeze ("to talk without significant purpose") cannot be determined through an analysis of the meaning of its individual words. The noncompositional view of idioms holds that their figurative meanings are directly predetermined in the mental lexicon in the same way the meanings of individual words are listed in a dictionary. According to the traditional view, learning the meaning of idioms requires that the speaker forms arbitrary links between idioms and their nonliteral meanings to recognize that (Ackerman, 1982; Prinz, 1983).

Contrary to the traditional view based on which idioms are noncompositional, many idiomatic phrases appear to be decomposable or analyzable, with the meanings of their parts contributing independently to their overall figurative meaning (Gibbs \&Nayak, 1989). Titone (1999) holds that the previous linguistic analyses and processing studies, suggesting traditional noncompositional definitions of idiomaticity, and processing models base on these definitions are inadequate by themselves. Idiomatic expressions exhibit a high degree of internal semantic structure, and literal processing does not stop when an idiom is encountered during comprehension. The compositional approach to idiom representation and processing is based on the notion that idiomatic meanings are built simultaneously out of literal word meanings and the specific interpretation of these word meanings within a particular context (Titone, 1999).

For instance, in the phrase pop the question, it is easy to detect that question refers to a marriage proposal when the verb pop is used to refer to the act of uttering it. Similarly, law in lay down the law refers to the code of conduct in a given situation when the verb phrase laying down is used to refer to the act of invoking the law.

Idioms like pop the question and spill the beans are decomposable, because each component obviously contributes to be overall meaning of the phrase. Idioms whose individual parts do not contribute to the overall figurative meanings are semantically nondecomposable (e.g., kick the bucket and shoot the breeze). This is because people experience difficulty in breaking these phrases in to their component parts (Gibbs \&Nayak, 1989).

The analyzability of idioms does not depend on the word string's being literally well formed (Gibbs \&Nayak, 1989). For instance, pop the question is literally irregular but semantically decomposable. All that matters for an idiom to be viewed as decomposable is for its parts to have meanings, either literal or figurative, that contribute independently to the phrase's overall figurative interpretation (Gibbs, 1994).

Teaching and learning idioms is one of the most difficult areas in which L2 teachers and learners are involved. Therefore, L2 scholars and teachers have always been searching for practical and effective teaching techniques for teaching idioms. Idioms make up a large proportion of any discourse, and the comprehension and production of them are the main parts of the studies of idiomaticity in both first and second language literature. A number of studies (e.g., Botelho da Silva \& Cutler 1993; Colombo 1993; Cronk\&Schweigert 1992; McGlone et al., 1994) focused on idiom comprehension. Cronk and Schweigert (1992) identified familiarity and literalness as measurable indications for the computation and representation of idiomatic meaning in the mental lexicon. Botelho da Silva and Cutler (1993) studied the role of ill-formedness in idiom processing while the case of ambiguity and the relationship between context and different types of idioms was the main interest of McGlone et al. (1994).

According to Cooper (1999) four theories try to explain how English native speakers comprehend idioms: the first called Idiom-list hypothesis (Bobrow\& Bell, 1973) which sates a native speaker who encounters an idiom first interprets it literally. If a literal meaning does not fit the context in which the expression is situated, then he searches for the idiom in question in special mental idiom lexicon. The second theory which is representation hypothesis (Swinney\& Cutler, 1979) considers idioms to be long words that are stored in the mental lexicon along with all other words and both the literal and figurative meanings of the expression are processed simultaneously. The third model, the direct access hypothesis (Gibbs, 1980; 1984; Schweigert, 1986), is an extension of the lexical representation hypothesis, for it posits that a native speaker rarely considers the literal meaning of an idiomatic expression but instead retrieves the figurative meaning directly from the mental lexicon. And finally, the composition model (Gibbs, 1994; Tabossi \& Zardon, 1995) which I explained earlier.

Giora's (1997) graded salience hypothesis is another hypothesis which came out of the discussion on idiom representation, processing, and comprehension, according to which, salient meanings of words or expressions are processed initially (if their lexicalized meaning can be retrieved directly from the mental lexicon rather than from the context) before less salient meanings are activated. Giora believed that metaphor and literal interpretations do not involve equivalent processes. The salient meanings of familiar and novel instances of metaphors, idioms, and irony are always accessed, and always initially, regardless of context, even rich and supportive context; that is, metaphor, idiom, and irony interpretation involves processing the literal meaning (see also Giora, 1999, Giora\& Fein, 1999). 
In the meantime, other studies (e.g., Arnold \& Hornett, 1990; Levorato \& Cacciari, 1992, 1995; Nippold \& Rudzinski, 1993; Titone 1994) have looked for the relationships between idioms comprehension or production, and age and awareness of semantic links and cognitive abilities. For instance, Nippold and Rudzinski (1993) like Arnold and Hornett (1990) and Levorato and Cacciari (1992, 1995) found that familiarity, idiom transparency, and idiom performance gradually improved as the participants' age increased.

Similarly, Titone (1994) found familiarity, compositionality, predictability, and literally to be important dimensions in the processing of L1 idioms. It is unfortunate that this intensity of research into L1 idiom processing and comprehension has not been matched by equal level interest among SLA researchers. However, Irujo (1986) utilized recognition and production tests to demonstrate that advanced students of English rely on knowledge of their native Spanish in order to comprehend and produce L2 idioms. She further observed that learners find those idioms which are identical in both L1 and L2 the easiest to comprehend and produce. Idioms which are similar in L1 and L2 present to learners with only somewhat more difficulty, although production tests reveal interference from Spanish. Those idioms which are completely different in L1 and L2, however, prove the most difficult for learners to comprehend and produce, with almost no positive or negative transfer between the two languages.

In an attempt to obtain information about the ways in which L2 learners process, comprehend, and interpret idiomatic expressions both in and out of context, Liontas (2001) found that idiom comprehension performance in Modern Greek significantly improves if contextual information is present. One key finding that emerged from the Liontas (1997, 2001) studies is that knowledge and understanding of vocabulary is directly linked to idiom performance regardless of whether contextual support is provided to L2 learners.

Boer and Demecheleer (2001) draw attention to the cultural aspects of teaching idioms. They claimed that the possible impact of cross-cultural variation on learners' interpreting idioms invites language teachers to give extra attention to figurative expression in the target language that relate to metaphoric themes that are less salient in the native language. Furthermore, they believe that an approach to teaching idioms will benefit from teacher's awareness of crosscultural as well as cross- linguistics differences.

In fact, several researchers have suggested that L2 learners, unlike L1 learners, appear to have considerable difficulties comprehending and producing idioms accurately (Cooper, 1998; Irujo, 1986, 1993). Sadeghilar (1993) focused on the application of translation in the process of learning idioms and found that identical idioms in both English and Persian would show positive transfer since they are the easiest to be comprehended and produced correctly. Similar idioms would show negative transfer and their comprehension is as high as identical idioms, but their productions reflect interference from Persian. Different idioms would show neither positive transfer nor negative one. Their comprehension and production seemed to be lower than those of other two types. Sadeghi (1995) also suggested that lexicon-semantic based approach in teaching English and idioms would lead to much better performance and comprehension for the Iranian L2 learners. The present study was intended to compare the efficiency of three different techniques for teaching idioms, namely, L1 translation, L2 definition and synonyms, and pictorial representation of the idioms in terms of L2 learners' mastery of these idioms in the Iranian context. Also, it aimed to see if there was any interaction between the three techniques of teaching idioms, and learning the form and meaning of the same idioms. And also this study was to identify if these teaching approaches had different effects on the performance of the L2 learners on the recognition test compared with their performance on the production test. This study tried to answer the following questions:

1-Does the techniques of using L1 translation, L2 definition and synonym, and picture, have a significant effect on L2 learning of both meaning and form of decomposable idioms as measured through a recognition task?

2-Does the technique of using L1 translation, L2 definition and synonym, and picture, have a significant effect on L2 learning of both meaning and form of decomposable idioms as measured through a production task?

3-If there is any effect of instruction type on L2 learning of decomposable idioms, will this effect be maintained over a period of three weeks?

Hopefully, the results of this study will help L2 teachers to learn which type of teaching techniques are more effective for which type of idioms. Furthermore, better learning of idiomatic expressions helps L2 learners communicate better in the L2 and improves their ability in other skills such as reading and listening.

\section{METHODOLOGY}

\section{A. Participants}

The participants were selected from 120 Iranian TEFL undergraduates who were studying in four conversation classes at Islamic Azad University of Najaf Abad. They were homogenized through an Oxford Placement Test. All the participants took the Oxford Placement Test. Those students who scored one standard deviation below and one standard deviation above the mean were selected for the study. Only 68 students were selected. The idioms were presented by picture in the first class; in the second class, the Persian translation equivalents of the idioms were provided; and the participants in third and fourth class were taught the idioms using English definition.

\section{B. Materials}


Four instruments were used to collect the necessary data: First, the Oxford Placement Test (OPT) is a grammar test including 100 items, each having three choices. The test naturally starts with some examples which help students to do the test. It was used in order to homogenize students based on their general English proficiency. Second, a pretest was given to the participants three weeks before the experiment in order to find out whether the learners knew the meaning of idioms or not. Then, based on the results of the pretest, the idioms that were known even by one student were crossed out and replaced by other idioms. In addition, in order to decide on the decomposability/nondecomposability of the idioms, the researcher used Titone and Connine's (1994) classification. Third, a multiple-choice test on form and one on meaning of idioms, as the immediate and delayed recognition tests, were given to the participants. Each of these two tests included 20 items, 10 of which were on the L2 idioms (10 decomposable idioms) and 10 were fillers. It should be noted that in the form recognition test, the participants were asked to choose the best answer that completed each idiom, and in the meaning recognition test, they were asked to choose the correct equivalent of the idiom. In addition, the form recognition test was handed out to the participant first. Forth, after three weeks, the participants took the delayed production posttest on form and meaning of the idioms in the form of fill-in-the-blanks. This test included $10 \mathrm{~L} 2$ idioms, and the participants were asked to complete the idioms in the blanks.

All the tests were piloted with a smaller sample of the same population. The reliability of all tests was measured by KR-21, which ranged from .83 to .88 . The supervisor and advisor of the researcher confirmed the validity of the tests.

\section{Procedure}

The following steps were taken to collect the necessary data. First, the participants were homogenized through the OPT. Then, the selected idioms were given to the participants in the pretest to translate into Persian three weeks before the experiment to ensure the participants' unawareness of the idioms. After that, the idioms that were known even by one student were crossed out. Then, the participants who were studying in four conversation classes were randomly assigned to the three experimental groups. The idioms were presented by picture to the first group, the Persian translation equivalents to the second group, and the English definitions to the third and fourth groups. All the idioms were, then, reviewed in a separate session for each experimental group. It should be mentioned that the medium of instruction was English in all classes. In the next session, the participants received two recognition tests in the form of multiple-choice and the same recognition as well as one production test in the form of fill-in-the-blanks were handed out to them three weeks later (first on form and then on meaning). The delayed posttests were given in two following sessions: first, the production, and then, the recognition. Beforehand, the recognition and production tests were piloted with similar group of students in order to ensure the clarity of instructions and questions and to determine the reliability of the test as well as the time needed for answering the tests. The time needed for conducting the recognition test was about 10 minutes. This time was about 20 minutes for the production test.

\section{DATA ANALYSIS}

As seen in Tables 1, a One-way ANOVA run on the mean scores of the participants on the OPT shows there was no significant differences among the participants, $F(2,67)=1.228, p=.300$.

TABLE 1.

A ONE-WAY ANOVA FOR THE OPT

ANOVA

proficieny
\begin{tabular}{|l|r|r|r|r|r|}
\hline & \multicolumn{1}{c|}{ Sum of } & df & Mean Square & F & Sig. \\
\hline Between Groups & 68.633 & 2 & 34.317 & 1.228 & .300 \\
Within Groups & 1816.352 & 65 & 27.944 & & \\
Total & 1884.985 & 67 & & & \\
\hline
\end{tabular}

As Table 3 shows, a one-way ANOVA between groups analysis of variance was conducted to explore the impact of instruction types on learning the meaning of decomposable idioms, as measured by the first recognition test. There was a statistically significant difference at the $p<.05$ level in the scores for the three groups: $F(2,677)=23.778, p=.000$. Also a one-way ANOVA between groups analysis of variance was conducted to explore the impact of instruction types on learning the form of decomposable idioms, as measured by the first posttest. There was a statistically significant difference at the $p<.05$ level in the scores for the three groups: $F(2,677)=29.165, p=.000$. 
TABLE2.

ONE-WAY ANOVA FOR THE MEANING AND FORM SCORES OF DECOMPOSABLEIDIOMS IN THE FIRST RECOGNITION POSTTEST

\begin{tabular}{|c|c|c|c|c|c|c|}
\hline \multicolumn{7}{|c|}{ ANOVA } \\
\hline & & $\begin{array}{l}\text { Sum of } \\
\text { Squares }\end{array}$ & df & Mean Square & $F$ & \\
\hline meaning test scores & $\begin{array}{l}\text { Between Groups } \\
\text { Within Groups } \\
\text { Total }\end{array}$ & $\begin{array}{r}8.434 \\
120.061 \\
128.494\end{array}$ & $\begin{array}{r}2 \\
677 \\
679\end{array}$ & $\begin{array}{r}4.217 \\
.177\end{array}$ & 23.778 & .000 \\
\hline form test scores & $\begin{array}{l}\text { Between Groups } \\
\text { Within Groups } \\
\text { Total }\end{array}$ & $\begin{array}{r}12.498 \\
145.055 \\
157.553\end{array}$ & $\begin{array}{r}2 \\
677 \\
679\end{array}$ & $\begin{array}{r}6.249 \\
.214\end{array}$ & 29.165 & .000 \\
\hline
\end{tabular}

Post hoc tests were run to spot which groups performed differently. Table 3 shows the results. As the post hoc tests show, the following means are significantly different. The performance of the picture group on learning the meaning of decomposable idioms is significantly better than the translation group (mean difference .182) and the English definition (.267). However, no significant difference between the English definition and the translation groups is found.Also, the performance of the picture group on learning the form of decomposable idioms has been significantly better than the translation group (mean difference .177) and the English definition (mean difference .330). In addition, the performance of the translation group is significantly better than the English definition (mean difference .153) as far as form is concerned.

TABLE3.

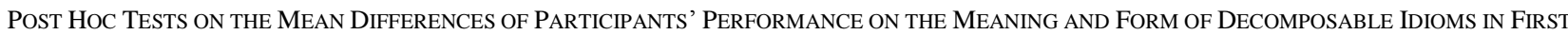
RECOGNITION POSTTEST

Multiple Comparisons

\begin{tabular}{|c|c|c|c|c|c|c|c|}
\hline \multirow[b]{2}{*}{ Dependent Variable } & \multirow[b]{2}{*}{ (I) instruction type } & \multirow[b]{2}{*}{ (J) instruction type } & \multirow{2}{*}{$\begin{array}{c}\text { Mean } \\
\text { Difference } \\
(1-J)\end{array}$} & \multirow[b]{2}{*}{ Std. Error } & \multirow[b]{2}{*}{ Sig. } & \multicolumn{2}{|c|}{ 95\% Confidence Interval } \\
\hline & & & & & & Lower Bound & Upper Bound \\
\hline \multirow[t]{6}{*}{ meaning test scores } & picture & translation & $.182^{\star}$ & .040 & .000 & .08 & .28 \\
\hline & & English defintion & $.267^{*}$ & .039 & .000 & 17 & .36 \\
\hline & translation & picture & $-.182^{\star}$ & .040 & .000 & -.28 & -.08 \\
\hline & & English defintion & .085 & .039 & .098 & -.01 & .18 \\
\hline & English defintion & picture & $-.267^{\star}$ & .039 & .000 & -.36 & -.17 \\
\hline & & translation & -.085 & .039 & .098 & -.18 & .01 \\
\hline \multirow[t]{6}{*}{ form test scores } & picture & translation & $.177^{\star}$ & .044 & .000 & .07 & .29 \\
\hline & & English defintion & $.330^{*}$ & .043 & .000 & .22 & .44 \\
\hline & translation & picture & $-.177^{\star}$ & .044 & .000 & -.29 & -.07 \\
\hline & & English defintion & $.153^{\star}$ & .043 & .002 & .05 & .26 \\
\hline & English defintion & picture & $-.330^{*}$ & .043 & .000 & -.44 & -.22 \\
\hline & & translation & $-.153^{\star}$ & .043 & .002 & -.26 & -.05 \\
\hline
\end{tabular}

${ }^{*}$. The mean difference is significant at the .05 level.

A mixed between within-subjects analysis of variance was conducted to assess the impact of the three different instructions on the participants' scores on learning the meaning of decomposable idioms as measured through the recognition posttests across two time periods. Table 4 shows the results:

TABLE4.

EFFECT OF TIME AND INSTRUCTION TYPE ON LEARNING THE MEANING OF DECOMPOSABLE IDIOMS

Tests of Within-Subjects Effects

\begin{tabular}{|c|c|c|c|c|c|c|c|}
\hline Source & & $\begin{array}{l}\text { Type III Sum } \\
\text { of Squares }\end{array}$ & df & Mean Square & $\mathrm{F}$ & Sig. & $\begin{array}{c}\text { Partial Eta } \\
\text { Squared }\end{array}$ \\
\hline \multirow[t]{4}{*}{ time } & Sphericity Assumed & 1.444 & 1 & 1.444 & 13.818 & .000 & .021 \\
\hline & Greenhouse-Geisser & 1.444 & 1.000 & 1.444 & 13.818 & .000 & .021 \\
\hline & Huynh-Feldt & 1.444 & 1.000 & 1.444 & 13.818 & .000 & .021 \\
\hline & Lower-bound & 1.444 & 1.000 & 1.444 & 13.818 & .000 & .021 \\
\hline \multirow[t]{4}{*}{ time * instructiontype } & Sphericity Assumed & .892 & 2 & .446 & 4.268 & .014 & .013 \\
\hline & Greenhouse-Geisser & .892 & 2.000 & .446 & 4.268 & .014 & .013 \\
\hline & Huynh-Feldt & .892 & 2.000 & .446 & 4.268 & .014 & .013 \\
\hline & Lower-bound & .892 & 2.000 & .446 & 4.268 & .014 & .013 \\
\hline \multirow[t]{4}{*}{ Error(time) } & Sphericity Assumed & 68.642 & 657 & .104 & & & \\
\hline & Greenhouse-Geisser & 68.642 & 657.000 & .104 & & & \\
\hline & Huynh-Feldt & 68.642 & 657.000 & .104 & & & \\
\hline & Lower-bound & 68.642 & 657.000 & .104 & & & \\
\hline
\end{tabular}

There was a substantial main effect for time at the $p<.05$ level in the scores for the three groups: $F(1,657)=13.818$, $p=.000$. The effect size, calculated using eta squared, was 0.21 with three types of instructions across the two time periods. And, it shows that the actual difference in mean scores between the groups was quite small. There was 
significant interaction between the method type and time on learning the meaning of decomposable idioms at the $p<.05$ level in the scores for the three groups: $F(2,657)=4.268, p=.014$, it shows that the actual difference in mean scores between the groups was quite small. The effect size, calculated using eta squared, was 0.13 with the three types of instructions across the two time periods.

The table 5 illustrates participants' performance on the meaning of decomposable in recognition posttest across two time periods.

TABLE5.

Performance on the Meaning of Decomposable in ReCOgnition Posttest across Two Time Periods

Tests of Between-Subjects Effects

Measure: MEASURE_1

Transformed Variable: Average
\begin{tabular}{|l|r|r|r|r|r|r|}
\hline Source & $\begin{array}{r}\text { Type III Sum } \\
\text { of Squares }\end{array}$ & df & Mean Square & \multicolumn{1}{c|}{ F } & Sartial Eta \\
\hline Intercept & 801.743 & 1 & 801.743 & 3609.827 & .000 & .000 \\
instructiontype & 10.486 & 2 & 5.243 & 23.607 & .846 \\
Error & 145.920 & 657 & .222 & & .067 \\
\hline
\end{tabular}

Table 5 shows that there was a significant effect of the three types of techniques on teaching of both types of idioms over a period of three weeks on learning the meaning of decomposable idioms, $F(2,657)=23.607, p=.000$. Despite reaching statistical significance, the actual difference in mean scores between the groups was medium. The effect size calculated using eta squared was 0.067 with three types of instructions.

Post hoc tests were run to spot which groups performed differently. Table 6 shows the results. As the post hoc tests show the following means are significantly different. Over a period of three weeks, the performance of the picture group on learning the meaning of decomposable idioms is significantly better than the performance of the translation group (mean difference.14) and also the English definition group (mean difference.21). However, no significant difference between the English definition and translation groups is found.

TABLE6.

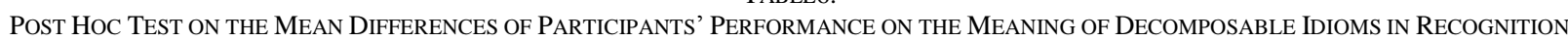
POSTTEST ACROSS Two TIME PERIODS

Multiple Comparisons

Measure: MEASURE 1

Scheffe

\begin{tabular}{|c|c|c|c|c|c|c|}
\hline \multirow[b]{2}{*}{ (I) instruction type } & \multirow[b]{2}{*}{ (J) instruction type } & \multirow{2}{*}{$\begin{array}{c}\text { Mean } \\
\text { Difference } \\
(I-J)\end{array}$} & \multirow[b]{2}{*}{ Std. Error } & \multirow[b]{2}{*}{ Sig. } & \multicolumn{2}{|c|}{$95 \%$ Confidence Interval } \\
\hline & & & & & Lower Bound & Upper Bound \\
\hline \multirow[t]{2}{*}{ picture } & translation & $.14^{*}$ & .032 & .000 & .06 & .22 \\
\hline & English defintion & $.21^{*}$ & .031 & .000 & .14 & .29 \\
\hline \multirow[t]{2}{*}{ translation } & picture & $-.14^{*}$ & .032 & .000 & -.22 & -.06 \\
\hline & English defintion & .07 & .032 & .076 & -.01 & .15 \\
\hline \multirow[t]{2}{*}{ English defintion } & picture & $-.21^{*}$ & .031 & .000 & -.29 & -.14 \\
\hline & translation & -.07 & .032 & .076 & -.15 & .01 \\
\hline
\end{tabular}

Based on observed means.

*. The mean difference is significant at the .05 level.

A mixed between within-subjects analysis of variance was conducted to assess the impact of the three different methods on the participants' scores on learning the form of decomposable idioms as measured through the recognition posttest across the two time periods. The results are illustrated in Table 7:

TABLE 7.

EFFECT OF TIME AND InSTRUCTION TYPE ON LEARNING THE FORM OF DECOMPOSABLE IDIOMS

Tests of Within-Subjects Effects

\begin{tabular}{|c|c|c|c|c|c|c|c|}
\hline Source & & $\begin{array}{l}\text { Type III Sum } \\
\text { of Squares }\end{array}$ & df & Mean Square & $\mathrm{F}$ & Sig. & $\begin{array}{c}\text { Partial Eta } \\
\text { Squared }\end{array}$ \\
\hline \multirow[t]{4}{*}{ time } & Sphericity Assumed & 1.169 & 1 & 1.169 & 8.826 & .003 & .013 \\
\hline & Greenhouse-Geisser & 1.169 & 1.000 & 1.169 & 8.826 & .003 & .013 \\
\hline & Huynh-Feldt & 1.169 & 1.000 & 1.169 & 8.826 & .003 & .013 \\
\hline & Lower-bound & 1.169 & 1.000 & 1.169 & 8.826 & .003 & .013 \\
\hline \multirow[t]{4}{*}{ time * instructiontype } & Sphericity Assumed & 2.207 & 2 & 1.104 & 8.332 & .000 & .025 \\
\hline & Greenhouse-Geisser & 2.207 & 2.000 & 1.104 & 8.332 & .000 & .025 \\
\hline & Huynh-Feldt & 2.207 & 2.000 & 1.104 & 8.332 & .000 & .025 \\
\hline & Lower-bound & 2.207 & 2.000 & 1.104 & 8.332 & .000 & .025 \\
\hline \multirow[t]{4}{*}{ Error(time) } & Sphericity Assumed & 87.019 & 657 & .132 & & & \\
\hline & Greenhouse-Geisser & 87.019 & 657.000 & 132 & & & \\
\hline & Huynh-Feldt & 87.019 & 657.000 & .132 & & & \\
\hline & Lower-bound & 87.019 & 657.000 & 132 & & & \\
\hline
\end{tabular}


There was a substantial main effect for time at the $p<.05$ level in the scores for the three groups: $F(1,657)=8.826, p$ $=.003$. The effect size, calculated using eta squared, was 0.013 with the three types of instructions across the two time periods. And, it shows that the actual difference in mean scores between the groups was quite small. There was a significant interaction between the method type and time on learning the form of decomposable idioms at the $p<.05$ level in the scores for the three groups: $F(2,657)=8.332, p=.000$, and it shows that the actual difference in mean scores between the groups was quite small. The effect size, calculated using eta squared was 0.025 with the three types of instructions across the two time periods:

TABLE 8.

PERFORMANCE ON LEARNING THE FORM OF DECOMPOSABLE IDIOMS

Tests of Between-Subjects Effects

Measure: MEASURE_1

Transformed Variable: Average

\begin{tabular}{|l|r|r|r|r|r|r|}
\hline Source & $\begin{array}{r}\text { Type III Sum } \\
\text { of Squares }\end{array}$ & df & Mean Square & \multicolumn{1}{c|}{ F } & Sig. & \multicolumn{1}{c|}{$\begin{array}{c}\text { Partial Eta } \\
\text { Squared }\end{array}$} \\
\hline Intercept & 594.796 & 1 & 594.796 & 2090.859 & .000 & .761 \\
instructiontype & 14.248 & 2 & 7.124 & 25.043 & .000 & .071 \\
Error & 186.900 & 657 & .284 & & & \\
\hline
\end{tabular}

Table 8 shows the results that there was a significant effect of the three types of techniques on learning both types of idioms over a period of three weeks on learning the form of decomposable idioms, $F(2,657)=25.043, p=.000$, and it shows that the actual difference in mean scores between the groups was medium. The effect size, calculated using eta squared, was 0.071 with the three types of instructions. Post hoc tests were run to spot which groups performed differently. Table 9 shows the results. As the post hoc tests show, the following means are significantly different. Over a period of three weeks, the performance of the picture group on learning the form of decomposable idioms is significantly better than the performance of the translation group (mean difference.16) and English definition group (mean difference.25). However, no significant difference between the English definition and translation groups was found:

TABLE9.

Post Hoc test on the MeAn DifFEREnCES of PARTICIPANTS' PERFORMANCE ON THE Form OF DECOMPOSABLE IDIOMS IN RECOGNITION PostTests ACross Two TIME PERIODs

Multiple Comparisons

Measure: MEASURE 1

\begin{tabular}{|c|c|c|c|c|c|c|}
\hline \multirow[b]{2}{*}{ (I) instruction type } & \multirow[b]{2}{*}{ (J) instruction type } & \multirow{2}{*}{$\begin{array}{c}\text { Mean } \\
\text { Difference } \\
(1-J)\end{array}$} & \multirow[b]{2}{*}{ Std. Error } & \multirow[b]{2}{*}{ Sig. } & \multicolumn{2}{|c|}{ 95\% Confidence Interval } \\
\hline & & & & & Lower Bound & Upper Bound \\
\hline \multirow[t]{2}{*}{ picture } & translation & $.16^{\star}$ & .036 & .000 & .07 & .25 \\
\hline & English defintion & $.25^{\star}$ & .036 & .000 & .16 & .34 \\
\hline \multirow[t]{2}{*}{ translation } & picture & $-.16^{\star}$ & .036 & .000 & -.25 & -.07 \\
\hline & English defintion & .08 & .036 & .065 & .00 & .17 \\
\hline \multirow[t]{2}{*}{ English defintion } & picture & $-.25^{\star}$ & .036 & .000 & -.34 & -.16 \\
\hline & translation & -.08 & .036 & .065 & -.17 & .00 \\
\hline
\end{tabular}

Based on obsened means.

${ }^{\star}$. The mean difference is significant at the .05 level.

TABLE 10.

ONE-WAy ANOVA FOR THE MEANING AND Form SCORES OF DECOMPOSABLE IDIOMS IN DELAYED PRODUCTION TEST

ANOVA

\begin{tabular}{|ll|r|r|r|r|r|}
\hline & & \multicolumn{1}{c|}{$\begin{array}{c}\text { Sum of } \\
\text { Squares }\end{array}$} & df & Mean Square & F & Sig. \\
\hline meaning delay & Between Groups & 11.039 & 2 & 5.519 & 30.025 & .000 \\
& Within Groups & 120.773 & 657 & .184 & & \\
& Total & 131.812 & 659 & & & \\
\hline form delay & Between Groups & 14.119 & 2 & 7.060 & 32.284 & .000 \\
& Within Groups & 143.667 & 657 & .219 & & \\
& Total & 157.786 & 659 & & & \\
\hline
\end{tabular}

There was a statistically significant difference at the $p<.05$ level in the scores for the three groups: $F(2,657)=8.852$, $p=.000$.Also, a one-way ANOVA between groups analysis of variance was conducted to explore the impact of the instruction types on learning the form of decomposable idioms, as measured by the second posttest. There was a statistically significant difference at the $p<.05$ level in the scores for the three groups: $F(2,657)=9.336, p=.000$.

Post hoc tests were run to spot which groups performed differently. Table 11 shows the results. 
TABLE 11.

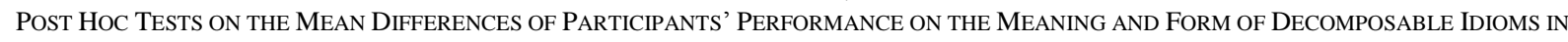
DELAYED PRODUCTION TEST

Multiple Comparisons

\begin{tabular}{|c|c|c|c|c|c|c|c|}
\hline \multirow[b]{2}{*}{ Dependent Variable } & \multirow[b]{2}{*}{ (I) instruction type } & \multirow[b]{2}{*}{ (J) instruction type } & \multirow{2}{*}{$\begin{array}{c}\text { Mean } \\
\text { Difference } \\
(I-J)\end{array}$} & \multirow[b]{2}{*}{ Std. Error } & \multirow[b]{2}{*}{ Sig. } & \multicolumn{2}{|c|}{ 95\% Confidence Interval } \\
\hline & & & & & & Lower Bound & Upper Bound \\
\hline \multirow[t]{6}{*}{ delayed meaning scores } & picture & translation & $.095^{\star}$ & .037 & .038 & .00 & .19 \\
\hline & & English defintion & $.152^{*}$ & .036 & .000 & .06 & .24 \\
\hline & translation & picture & $-.095^{\star}$ & .037 & .038 & -.19 & .00 \\
\hline & & English defintion & .057 & .037 & .310 & -.03 & .15 \\
\hline & English defintion & picture & $-.152^{\star}$ & .036 & .000 & -.24 & -.06 \\
\hline & & translation & -.057 & .037 & .310 & -.15 & .03 \\
\hline \multirow[t]{6}{*}{ delayed form scores } & picture & translation & $.161^{\star}$ & .044 & .001 & .05 & .27 \\
\hline & & English defintion & $.161^{*}$ & .043 & .001 & .06 & .27 \\
\hline & translation & picture & $-.161^{\star}$ & .044 & .001 & -.27 & -.05 \\
\hline & & English defintion & .000 & .043 & 1.000 & -.11 & .11 \\
\hline & English defintion & picture & $-.161^{*}$ & .043 & .001 & -.27 & -.06 \\
\hline & & translation & .000 & .043 & 1.000 & -.11 & .11 \\
\hline
\end{tabular}

*. The mean difference is significant at the .05 level.

As the post hoc tests show, the following means are significantly different. The performance of the picture group on learning the meaning of decomposable idioms is significantly better than the translation group (mean difference .095) and the English definition group (.152). However, no significant difference between the English definition and the translation groups was found. Also, the performance of the picture group on learning the form of decomposable idioms has been significantly better than the translation group (mean difference .161) and the English definition group (mean difference .043) in the recognition delayed posttest. However, as far as form is concerned, no significant difference between the English definition and the translation groups is found.

\section{DISCUSSION AND CONCLUSION}

The first research question asked whether there was any significant effect of the type of instruction, using L1 translation, using L2 definitions and synonyms, and using pictures on learning both meaning and form of decomposable idioms as measured through a recognition task. The analyses of the data regarding both meaning and form showed that the participants in the picture group outperformed the other two groups; however, as far as the form was concerned, the L1 translation group outperformed the L2 group as well. Regarding the positive effect of pictures, it seems that addition of a picture enhanced the learner's understanding of meaning as well as preserving the form of the idiom in the memory. The positive effect of pictures on word learning was shown by Plass, Chun, Mayer, and Leutner, (1998). This is in line with the claim of the generative theory of multimedia teaching (Mayer, 1997, 2001). As Mayer (2005b) believes, it is through two channels that human beings represent and manipulate knowledge: a visual-pictorial and an auditory-verbal (Mayer, 2002, 2005b). Cognitively, it could be argued that presentation of the information visually and textually might cause L2 learners to process information through different channels. This may engage L2 learners in active processing within the channels, including selecting relevant words and pictures, organizing them into coherent pictorial and verbal models, and integrating them with each other and with the previous mental knowledge. Furthermore, Mayer (2005b) shows the best performance of the participants when both visual and textual information was selected, moderate when only one mode was selected and worst when neither was selected. The same findings were reported by Al-Seghayer (2001), Chun and Plass (1996), Yeh and Wang, (2003), and Yoshii and flaitz (2002), too.

The second research question asked whether there was any significant effect of the type of instruction, using L1 translation, using L2 definition and synonym, and using picture on L2 learning of both meaning and form of decomposable idioms as measured through a production task. The answer to this research question is "yes." The results show that the pictures could significantly improve L2 learners' production of L2 idioms regarding both meaning and form. The better performance of the L1 group over the L2 group in terms of meaning might show that in production the need for closer proximity to the conceptual system is perceived. This proximity seems to be through L1. As Able (2003) believes, lack of an idiom entry for an idiom, which is mainly the case for decomposable idioms, increases the reliance of the language processor on activating the conceptual representations that are organized around world knowledge and are nonlinguistic and represented at the cognitive level. This conceptual system is believed to be accessed through L1, especially for nonadvanced L2 learners.

The third research question asked whether the effect of type of instruction on the learning of decomposable idioms, if there was any, was maintained over a delay of three weeks. As data analysis of the delayed recognition test showed, the picture group surpassed the other two groups in all conditions and a few differences that existed between the L1 group and the L2 group disappeared. In other words, the advantage of having additional channel of processing input manifested itself in the delayed recognition test as well. In addition, as the results of the mixed between-within-subjects analysis of variance show, the performance was generally better in the delayed recognition test than the immediate, although the effect size is small in almost all cases. 
To sum up, as the quantitative results of this study show, better recognition and production of form and meaning of the two types of idioms occurs when both channels (verbal and visual) are engaged in almost all cases.

\section{REFERENCES}

[1] Abel, B. (2003). English idioms in the first language and second language lexicon: A dual representation approach. Second Language Research, 19(4), 329-358.

[2] Ackerman, B. P. (1982). On comprehending idioms: Do children get the picture? Journal of Experimental Child Psychology, $33,439-454$.

[3] Al-Seghayer, K. (2001). The effect of multimedia annotation modes on L2 vocabulary acquisition: A comparative study. Language Learning \& Technology, 5(1), 202-232.

[4] Arnold, K. M., \& Hornett, D. (1990). Teaching idioms to children who are deaf. Teaching Exceptional Children, 22(4), 14-17.

[5] Bobrow, S. A., \& Bell, S. M. (1973). On catching on to idiomatic expressions. Memory and Cognition 1, 343-346.

[6] Boers, F., \& Demecheleer, M. (2001). Measuring the impacts of cross-cultural differences on learners' comprehension of imageable idioms. ELT Journal, 55(3), 255-262.

[7] Botelho da Silva, T., \& Cutler, A. (1993). Ill-formedness and transformability in Portuguese idioms. In C. Cacciari \& P. Tabossi (Eds.), Idioms: Processing, structure, and interpretation (pp. 27-55). Hillsdale, NJ: Lawrence Erlbaum Associates.

[8] Chomsky, N. (1965). Aspects of theory of syntax. Cambridge, MA: MIT Press.

[9] Chomsky, N. (1980). Rules and representations. NY: Colombia University Press.

[10] Chun, D. M., \& Plass, J. L. (1996). Effects of multimedia annotations on vocabulary acquisition. The Modern Language Journal, 80(2), 183-198.

[11] Colombo, L. (1993). The comprehension of ambiguous idioms in context. In C. Cacciari \& P. Tabossi (Eds.), Idioms: Processing, structure, and interpretation, (pp.163-200). Hillsdale, NJ: Lawrence Erlbaum Associates.

[12] Cooper, D. (1986). Metaphor. London: Blackwell Publisher.

[13] Cooper, T. C. (1998). Teaching idioms. Journal of Foreign Language Annals, 31(2), 255-266.

[14] Cooper, T. C. (1999). Teaching idioms. Foreign Language Annals, 31, 255-266.

[15] Cooper, T. C. (1999). Processing of idioms by L2 learners of English. TESOL Quarterly, 33(2), 233-262.

[16] Cronk, B. C., \& Schweigert, W. A. (1992). The comprehension of idioms: The effects of familiarity, literalness, and usage. Applied Linguistics, 13(2), 131-146.

[17] Fraser, B. (1970). Idioms within a transformation grammar. Foundations in Language, 6, 22-42.

[18] Gibbs, R. W. Jr. (1980). Spilling the beans on understanding and memory for idioms in conversation. Journal of Memory \& Cognition, 8(2), 149-156.

[19] Gibbs, R. W. Jr. (1984). Literal meaning and psychological theory. Cognitive Science, 8, 275-304.

[20] Gibbs, R. W. Jr. (1994). The poetics of mind: Figurative thought, language, and understanding. NY: Cambridge University Press.

[21] Gibbs, R., \& Nayak, N. (1989). Psycholinguistic studies on the syntactic behavior of idioms. Cognitive Psychology, 21, 100138.

[22] Giora, R., \& Fein, O. (2000). On understanding familiar and less-familiar figurative language. Journal of Pragmatics, 31 , 16011618.

[23] Giora, R. (1997). On the priority of salient meanings: Studies of literal and figurative language. Journal of Pragmatics, 31, 919-929.

[24] Irujo, S. (1986). Don't put your leg in your mouth: Transfer in the acquisition of idioms in a second language. TESOL Quarterly, 20, 287-304.

[25] Irujo, S. (1993). Steering clear: Avoidance in the production of idioms. Journal of IRAL, 31(3), 205-219.

[26] Levorato, M. C., \& Cacciari, C. (1992). Children's comprehension and production of idioms: The role of context and familiarity. Journal of Child Language, 19(2), 415-433.

[27] Levorato, M. C., \& Cacciari, C. (1995). The effects of different tasks on the comprehension and production of idioms in children. Journal of Experimental Child Psychology, 60(2), 261-283.

[28] Liontas, J. I. (1997, November). Building castles in the air: The comprehension processes of Modern Greek idioms. Paper presented at the 15th International Symposium on Modern Greece, Kent State University, Kent, OH.

[29] Liontas, J. I. (2001). That's all Greek to me! The comprehension and interpretation of modern Greek phrasal idioms. The Reading Matrix: An International Online Journal, 1(1), 1-32.

[30] Mayer, R. E. (1997). Multimedia learning: Are we asking the right questions. Educational Psychologist, 32, 1-19.

[31] Mayer, R. E. (2001). Multimedia learning. Cambridge University Press. Educational Psychologist, 32, 1-19.

[32] Mayer, R. E. (2002). Cognitive theory and the design of multimedia instruction: An example of the two way street between cognition and instruction. In D. F. Halpern \& M. D. Hakel, (Eds.), Applying the science of learning to university teaching and beyond (pp. 55-72). San Francisco: Jossey-Bass.

[33] Mayer, R. E. (2005b). Cognitive theory of multimedia learning. In R. E. Mayer (Ed.), The Cambridge handbook of multimedia learning (pp. 31-48). Cambridge University Press.

[34] McGlone, M. S., Glucksberg, S., \& Cacciari, C. (1994). Semantic productivity and idiom comprehension. Discourse Processes, 17(2), 167-190.

[35] Nippold, M. A., \& Rudzinski, M. (1993). Familiarity and transparency in idiom explanation: A developmental study of children and adolescents. Journal of Speech and Hearing Research, 36(4), 728-737.

[36] Plass, J. L., Chun, D. M., Mayer, R. E., \& Leutner, D. (1998). Supporting visual and verbal learning preferences in a secondlanguage multimedia learning environment. Journal of Educational Psychology, 90(1), 25-36.

[37] Prinz, P. M. (1983). The development of idiomatic meaning in children. Journal of Language and Speech, 26, $263-272$. 
[38] Sadeghi, B. (1995). The impact of lexico-semantic based approach on teaching idiomatic expressions. Unpublished master's thesis, Islamic Azad University, Najaf Abad, Iran.

[39] Sadeghilar, N. (1993). The role of transfer in the acquisition of idioms in a second language. Unpublished master's thesis, Islamic Azad University, Najaf Abad, Iran.

[40] Schweigert, W. A. (1986). The comprehension of familiar and less familiar idioms. Journal of Psycholinguistic Research, 15, $33-45$.

[41] Secord, W. A., \& Wiig, E. H. (1993). Interpreting figurative language expressions. Folia. Phoniatr, 45, 1-9.

[42] Sprenger, S. A., Levelt, W. J. M., \& Kempen, G. (2006). Lexical access during the production of idiomatic phrases. Journal of Memory and Language, 54,161-184.

[43] Swinney, D. A., \& Cutler, A. (1979). The access and processing of idiomatic expressions. Journal of Verbal Learning and Verbal Behavior, 18, 523-534.

[44] Tabossi, T., \& Zardon, F. (1995). The activation of idiomatic meaning. In M. E. Everaert, E. van der Linden, A. Schenk, \& R. Schreuder (Eds.), Idioms: Structural and psychological perspectives (pp.273-282). Hillsdale, NJ: Erlbaum.

[45] Titone, D. A., \& Connine, C. M. (1999). On the compositional and non compositional nature of idiomatic expressions. Journal of Pragmatics, 31, 1655-1674.

[46] Titone, D. A. \& Connine, C. M. (1994). Descriptive norms for 171 idiomatic expressions: Familiarity, compositionality, predictability, and literality. Metaphor and Symbolic Activity 9, 247-70.

[47] Yeh, Y., \& Wang, C. (2003). Effects of multimedia vocabulary annotations and learning styles on vocabulary learning. CALICO Journal 21(1), 131-144.

[48] Yoshii, M., \& Flaitz, J. (2002). Second language incidental vocabulary retention: The effect of picture and annotation types. CALICO Journal, 20(1), 33-58.

Zahra Fotovatnia is Assistant Professor of Applied Linguistics at Islamic Azad University, Najafabad Branch. She has been an instructor and a researcher for over 16 years. She has attended the following conferences: Metaphor Festival, Sweden, 2011; Second International Conference on Literature, language and Linguistics, Greece, 2009; EuroSLA 2007 UK; Asia TEFL, Malaysia; $8^{\text {th }}$ International European conference of Psychology, Spain; and ICP2004 Beijing. She has published articles in Journal of Social Sciences and Humanities of Shiraz University, 23, 1, 2006; Language Forum, 32, 1-2, 2006; and Pajjohesh in Educational Sciences, 2, 4, 2004. Her area of interest includes pedagogical phonetics and phonology, psycholinguistics, and Teaching Methodology.

Ghzal Khaki holds an M.A. in TEFL from Islamic Azad University, Najaf Abad Branch. She is currently teaching English at Isfahan language schools at various levels. Her areas of interest include discourse analysis, sociolinguistics, and L2 methodology. 